\title{
THE SARMATIAN BURIAL FROM "KIRPICHNYY" BARROW IN KUBAN REGION ${ }^{1}$
}

\author{
Natalya Yu. Limberis \\ Kuban State University, Krasnodar, Russian Federation \\ Ivan I. Marchenko \\ Kuban State University, Krasnodar, Russian Federation
}

\begin{abstract}
The paper is devoted to the rich Sarmatian burial from the destroyed mound. The burial was a pit with overlapping of narrow wooden poles or boards. The skeleton was laid stretched on its back, the skull was oriented to SSW. Sheep bones and an iron knife were located at the feet, near the pit wall. The assemblage of grave goods is quite various and informative: a bronze mirror, gold bracelets and earrings, necklaces with cornelian and chalcedony beads, glass beads on the legs and arms, flint nucleus, "whetstone" (assay stone), clay spindles, iron arrowheads and small grey clay bowl of Maeotian production. Cast mirrors of Prokhorov Type are often found in Sarmatian burial mounds of the Kuban region of the $3^{\text {rd }}-1^{\text {st }} \mathrm{c}$. BC. The bead types are typical for the Hellenistic period. The gold earrings are late replicas of the "lionheaded" earrings of the Northern Black Sea group. The magical items (nucleus, assay stone) have the closest analogies in Sarmatian assemblages of the early $1^{\text {st }} \mathrm{c}$. BC. The bronze fingerings of the late Latin type with spiral shields were spread in the Northern Black Sea region and among Kuban Maeotian tribes in the Roman period. However their appearance in this region probably refers to an earlier period. The gold jewellery, rich necklace, full quiver of arrows and items related to cult activities make it possible to attribute this assemblage to the category of elite burials of the Siracian nobility.
\end{abstract}

Key words: the Kuban region, mound, Sarmatian burial, grave goods, chronology, Siraces.

Citation. Limberis N.Yu., Marchenko I.I., 2019. The Sarmatian Burial from "Kirpichnyy" Barrow in Kuban Region. The Lower Volga Archaeological Bulletin, vol. 18, no. 1, pp. 178-191. (in Russian). DOI: https://doi.org/ 10.15688/nav.jvolsu.2019.1.14

УДК 930.26(470+571)

Дата поступления статьи: 01.02.2019

ББК 63.48(2) Дата принятия статьи: 09.03.2019

\section{САРМАТСКОЕ ПОГРЕБЕНИЕ ИЗ КУРГАНА «КИРПИЧНЫЙ» В ПРИКУБАНЬЕ 1}

\author{
Наталья Юрьевна Лимберис \\ Кубанский государственный университет, г. Краснодар, Российская Федерация \\ Иван Иванович Марченко \\ Кубанский государственный университет, г. Краснодар, Российская Федерация
}

Аннотация. Статья посвящена богатому сарматскому погребению из разрушенного кургана. Погре-
бальное сооружение представляло собой яму с перекрытием из узких деревянных жердей или плашек. Ске-
лет лежал вытянуто на спине, черепом на ЮЮЗ. В ногах, у стенки ямы, находились кости барана и железный
нож. Комплекс погребального инвентаря достаточно разнообразен и информативен: бронзовое зеркало,
золотые браслеты и серьги, халцедоновые и сердоликовые бусы, составлявшие ожерелье, а также стеклян-
ные бусы на руках и ногах, кремневый нуклеус, «оселок» (пробирный камень), глиняные пряслица, желез- 
ные наконечники стрел и сероглиняная мисочка меотского производства. Литые зеркала прохоровского типа часто встречаются в сарматских захоронениях Прикубанья III-І вв. до н.э. Типы бус характерны для эллинистического времени. Золотые серьги представляют собой поздние реплики «львиноголовых» серег северопричерноморской группы. Магические предметы (нуклеус, пробирный камень) находят ближайшие аналогии в богатых сарматских комплексах первой половины I в. до н.э. Бронзовые перстни позднелатенского типа со спиральным щитком довольно широко распространились в Северном Причерноморье и у меотов Прикубанья в римское время, но их появление в данном регионе, вероятно, относится к более раннему периоду. Золотые украшения, богатое ожерелье, полный колчан стрел и наличие среди инвентаря предметов, связанных с культовыми действиями, позволяют отнести захоронение к разряду элитных погребений сиракской знати. Хронология комплекса может быть ограничена пределами I в. до н.э.

Ключевые слова: Прикубанье, курган, сарматское погребение, погребальный инвентарь, хронология, Сираки.

Цитирование. Лимберис Н. Ю., Марченко И. И., 2019. Сарматское погребение из кургана «Кирпичный» в Прикубанье // Нижневолжский археологический вестник. Т. 18, № 1. С. 178-191. DOI: https://doi.org/ 10.15688/nav.jvolsu.2019.1.14

Погребение (рис. 1) было случайно обнаружено в кургане, разрушенном при добыче глины, и доследовано сотрудниками Краснодарской археологической экспедиции в 1987 г. под руководством А.М. Ждановского. Останец кургана до сих пор сохранился на западной окраине станицы Новотитаровской (Динской р-н Краснодарского края), рядом с действующим кирпичным заводом. В месте разрушения северной полы кургана был обнаружен обломок золотой серьги, а на глубине 3,85-4,3 м от вершины - выявлены следы поперечного перекрытия из узких деревянных жердей или плашек, непосредственно под которым находилась могильная яма, ориентированная по линии ЮЮЗCCВ. С3 край ямы был обрезан при добыче глины. ЮВ край ровный, образует прямой угол с ССВ торцевой стенкой, с ЮЮЗ стороны яма закругляется. Длина ямы - 2,5 м, сохранившаяся ширина - от 0,55 м до 0,8 м. ЮВ стенка была прослежена на высоту 0,71 м, торцевые стенки - 0,25-0,3 м. Дно ровное, с небольшим понижением к ЮЮЗ. По всему дну прослеживался бурый тлен от подстилки. Скелет человека, от которого сохранились истлевший череп и отпечатки костей, лежал вытянуто на спине, черепом на ЮЮЗ. Череп лежал на затылочной части. Правая рука была согнута в локте, кисть должна была находиться на животе, левая - незначительно согнута и отведена в сторону от туловища. Ноги были вытянуты, сближены в голенях.

Под черепом и шейными позвонками лежало бронзовое зеркало (рис. 1,1). Слева, у черепа, находилась золотая серьга (рис. 1,2). Справа и слева от черепа, на грудных позвон- ках, на зеркале и вокруг него было расчищено множество сердоликовых и несколько халцедоновых бусин (рис. 1,3,4). В центре ожерелья находилась крупная бусина из халцедона. Несколько бусин откатилось к левой руке и правому плечу.

На тлене спинных позвонков находились фрагменты серебряных «бляшек» (рис. 1,$5 ; 3,1$ ). В области предплечий лежали золотые браслеты (рис. 1,6,8), окруженные полукругом стеклянных бусин с внутренней позолотой (рис. 1,7,9).

В $18 \mathrm{~cm}$ от левого коленного сустава был расчищен большой «пучок» (более 80 шт.) спекшихся железных наконечников стрел (рис. 1,10 ). Два наконечника лежали отдельно - у нижнего конца правой голени, снаружи (рис. 1,10). В 17 см от правой голени была расчищена кучка мелких предметов: часть железного браслета (рис. 1,$11 ; 2,9)$, фрагменты бронзового перстня (рис. 1,12), стеклянные бусы с внутренней позолотой разных типов и одна плоская (рис. 1,13 ). Правее этого скопления (вдоль длинной стенки могильной ямы) прослеживался тлен от узкого деревянного предмета слегка изогнутой формы длиной 55 см (рис. 1,14). В нижней части голеней были расчищены многочисленные мелкие стеклянные бусы и бисер (рис. 1,15,16).

У стоп стояла сероглиняная чашечка (рис. 1,17). Под ее венчиком с ЮЮЗ стороны находился фрагмент острия железного ножа (рис. 1,18 ), а с ССВ - три глиняных пряслица (рис. 1,19). В 8 см к западу от чашечки лежали «оселок» (рис. 1,20$)$ и кремневый нуклеус (рис. 1,21). Рядом с этими предметами прослеживались пятна минеральной краски светло-фиолетового цвета. 
У ССВ стенки ямы был расчищен тлен костей передней ноги и ребер барана (рис. 1,22). У ребер лежала часть железного шила (рис. 1,$23 ; 2,4)$, а возле фаланг, у стенки ямы,два фрагмента железного ножа (рис. 1,$24 ; 2,5$ ).

При разборке погребения под затылочной частью черепа было найдено много сердоликовых бус. Под зеркалом выявлены остатки тлена, похожего на войлок.

Комплекс погребального инвентаря в общем типичен для сарматских захоронений Прикубанья, но в то же время достаточно разнообразен и информативен.

Зеркало (рис. 2,10) плоское, литое, с валиком по краю и маленькой заостренной ручкой с отверстием (диаметр - 19,5 см, длина ручки - 1,5 см), лежавшее под черепом, относится к характерному прохоровскому типу [Мошкова, 1963, с. 42, табл. 28, отдел II, тип 3]. Такие зеркала нередки и в сарматских погребениях Прикубанья III - начала I в. до н.э. [Марченко, 1996, с. 21, тип VII]. Например, зеркало этого типа происходит из погр. 3 кург. 1 у хут. Северный, которое А.С. Скрипкин в свое время широко датировал III-II вв. до н.э. [Скрипкин, 1984 , с. 221,223 , рис. 1]. Узкая датировка комплекса, по нашему мнению, ограничивается второй половиной II в. до н.э. [Marčenko, Limberis, 2008, s. 298, 382, Taf. 40, Kat.-Nr. 22]. К середине II в. до н.э. относится погр. 2 из кург. 1 у станицы Раздольной, в котором вместе с зеркалом был найден стеклянный канфар [Лимберис, Марченко, 2003, c. 109, № 10; Marčenko, Limberis, 2008, s. 297298, 381, Taf. 30, Kat.-Nr. 17]. Из раннесарматских комплексов Нижнего Подонья надежную датировку имеет погр. 20 кургана «Крестовый» могильника Алитуб, где такое зеркало встречено совместно с бронзовой сковородкой типа «Aylesford» [Шилов, 1975, с. 141-142, рис. 32,1; Максименко, 1983, с. 90 , рис. $37,4,6$; Раев, 1993 , с. 163 , рис. 1 ; Глебов, Толочко, 2016, с. 57, рис. 16]. В Прикубанье известны три сарматских захоронения со сковородками этого типа. Датировку погребений из Новоджерелиевского и «Овального» курганов мы ограничиваем второй четвертью I в. до н.э. Хронология комплекса из Воронежского кургана более широкая: в пределах второй - третьей четвертей этого столетия [Marčenko, Limberis,
2008, s. 286-287, 381, 382, Taf. 31, 32, 47, 48, 53, 54, Kat.-Nr. 18, 26, 29].

Бронзовый перстень (рис. 3,2) с пластинчатой шинкой и спиральным щитком, скрученным из узкой ленточки, был найден в составе компактной группы предметов (железный браслет, стеклянные бусы), лежавших отдельно, и которые, вероятно, можно отнести к категории погребальных даров. Перстни со спиральным щитком исследователи относят к украшениям позднелатенского типа, распространившимся в римское время в Северном Причерноморье [Кухаренко, 1959, с. 36; Трейстер, 1992a, с. 97, прим. 176 на с. 107, рис. 10,6; Трейстер, 1992б, с. 46, рис. 9,6; Гущина, Журавлев, 2016, с. 90-91]. Часто встречаются они и в меотских памятниках Прикубанья [Кононов, 2006, с. 125-126]. Подобные перстни, судя по материалам из могильников меотских городищ Елизаветинского № 1, хут. Ленина № 1, Старокорсунских № 2 и 3 , Спорное, были особенно популярны у меотов в I-II вв. н.э., что определяется по совместно встреченным фибулам разных типов. Причем наиболее ранние комплексы с перстнями датируются первой половиной I в. н.э. [Marčenko, Limberis, 2008, s. 388, Taf. 163, Kat.Nr. 156]. Принимая во внимание, что на территории кельтского мира перстни со спиральным щитком были широко распространены во II-I вв. до н.э., все-таки нельзя исключить, что и в Северном Причерноморье они могли появиться раньше, чем мы фиксируем по комплексам с фибулами.

Эти популярные в разных регионах украшения изготовляли разными способами. Н.В. Анфимов, описывая перстни этого типа, отмечал, что дужка у них пластинчатая (из расплющенной проволоки), со спиральным плоским щитком [Анфимов, 1961, с. 200, табл. IV, 15], или что они «изготовлены из узкой бронзовой полоски, концы которой оттянуты в проволоку, спирально свернутую и образующую щиток» [Анфимов, Анфимов, 1992, c. 45 , рис. 31,6$]$. В отличие от меотских перстней, которые, как правило, имеют пластинчатую шинку, известные нам изделия из синхронных памятников европейского Боспора и юго-западного Крыма чаще всего полностью круглопроволочные, то есть у них не только щиток скручен из проволоки, но и дужка / 
шинка не расплющена [Корпусова, 1983, с. 61, рис. $17,11,12$; Богданова, 1989 , с. 42 , табл. XII,2; Пуздровский, 2007, с. 86 рис. 35,4 ; Гущина, Журавлев, 2016, табл. 25,6, табл. 34,18, табл. 125,7 , табл. 126,12], хотя встречаются и пластинчатые - с плоской шинкой [Храпунов, 1992, с. 166-167, рис. 35,4]. Перстень же из «Кирпичного» кургана из этой весьма многочисленной серии украшений выделяется еще и скрученным из узкой ленточки щитком. Возможно, такая технологическая особенность является ранним хронологическим признаком для этих изделий.

Нуклеус (рис. 2,8; 4,2) карандашевидный из желтовато-серого кремня (длина $-4,7$ см) находился в ногах, слева. Такой же предмет (нуклеус из обсидиана), дополненный золотым колпачком с петелькой для подвешивания, был найден в погр. 15 кургана «Овальный», которое было нами датировано второй четвертью І в. до н.э. [Marčenko, Limberis, 2008, s. 382, Taf. 48,9, Kat.-Nr. 26]. Находки подвесок из разного материала в золотых колпачках довольно обычны для Прикубанья. Исследователи объединяют эти изделия из комплексов II-I вв. до н.э. в одну группу украшений [Mордвинцева, Трейстер, 2007, с. 71-72]. Подвеска из «Овального» кургана явно представляет собой не простое украшение, а амулет, наделявшийся в древности магической силой. К этой же категории сакральных предметов принадлежит и нуклеус из «Кирпичного» кургана.

Рядом с нуклеусом лежал «оселок» (рис. 2,$11 ; 4,1$ ) из плотного желтовато-коричневого песчано-глинистого с мелкими слюдяными блестками минерала (алевролита?) в форме стержня с плоскими торцами и круглым отверстием для подвешивания (длина 12,4 см). Этот предмет весьма напоминает пробирные камни в золотой оправе, известные в скифских и сарматских памятниках IV-I вв. до н.э. По внешним параметрам его можно сопоставить с «оселками» первой группы из мужских погребений могильника Филипповка 1. Главное отличие - отсутствие золотой оправы на верхнем конце, хотя эта деталь оформления для пробирных камней не всегда обязательна. Положение «оселка» в погребении рядом с сероглиняной чашечкой и нуклеусом в ногах скелета, прослеженное рядом пятно минеральной краски и следы сработан- ности в нижней части стержня, принимая во внимание наблюдения исследователей филипповских «оселков», наоборот, может свидетельствовать об использовании этого инструмента женщиной [Аникеева, 2010, с. 192-194; Аникеева, Яблонский, 2012, с. 47]. К сожалению, практическое отсутствие костей не позволило установить, мужчине или женщине принадлежало погребение из «Кирпичного» кургана. Наиболее близкими (территориально и хронологически) находками пробирных камней в Прикубанье являются «оселки» с золотыми колпачками из Зубовского кург. 1 и погр. 9 могильника Цемдолина. Здесь они были найдены вместе с фибулами, бронзовыми римскими сосудами и другими ценными вещами первой половины I в. до н.э. [Гущина, Засецкая, 1989, с. 79, 87-88, 127, табл. XI,7; Малышев, Трейстер, 1994, с. 66, табл. 8, 11; Marčenko, Limberis, 2008, s. 381, 382, Taf. 7,3, Taf. 59,2, Kat.-Nr. 5, 32].

Два золотых браслета (рис. 3,5,6; 4,3,4) из полой трубочки с запаянными концами, заходящими друг за друга (диаметр - 6 см), относятся к обычному типу, известному в богатых сарматских погребениях Прикубанья (Бойко-Понура, Песчаный, Зубовский 1) середины II - первой половины I в. до н.э. [Marčenko, Limberis, 2008, s. 381, 382, Taf. 9,5, Taf. 16,4, Taf. 49,4, Kat.-Nr. 5, 12, 27]. В Закубанье фрагменты гривен и/или браслета, изготовленных из полой трубочки, запаянной на концах, были найдены в кург. 1 могильника Псынафа II-I вв. до н.э. [Эрлих, 2014, с. 97, кат. № 167, 168].

Необычно выглядят золотые серьги (рис. 3,3,4; 4,5,6) с дужкой из крученой проволоки, с овальной полой бусиной из двух продольных половин, орнаментированной напаянными спиральными пирамидками из тонкой проволочки, скрученными в 6 оборотов (диаметр дужки - 2,8 см, размеры бусины - 2,3 × 1,3 см). Одна серьга - целая, но деформирована; от второй сохранилась часть дужки с фрагментом бусины. Серьги подобной конструкции из двух полых (но поперечных) половин известны в меотских памятниках Кубани II-I вв. до н.э. Одна половина бусины оформлялась в виде бутона, другая - оттиснута штампом в виде схематичной мордочки льва [Мордвинцева и др., 2010, с. 15 , кат. № 109, 197, 233, 549]. 
В Причерноморском регионе встречаются и экземпляры таких серег, украшенные напаянными конусами из спиральных оборотов проволоки, но с шариками зерни наверху [Мордвинцева, Трейстер, 2007, с. 102]. Серьга, бусина которой оформлена в виде бутона с редуцированной мордочкой льва, была найдена в погр. 48 кург. 1 могильника Псенафа, которое датировано исследователями I в. до н.э. [Эрлих, Чандрасекаран, 2013, с. 674-675, рис. 2,1; Эрлих, 2014, с. 95, кат. № 163]. Скорее всего, серьги (по крайней мере, одна из них) из погребения в «Кирпичном» кургане также представляют собой поздние реплики «львиноголовых» серег северопричерноморской группы.

Ожерелье состояло из каменных бус двух типов. Бусы халцедоновые округлые (4 экз.), из глухого голубоватого камня относятся к типу 4а [Алексеева, 1982, с. 12]. Размеры бусин разные: самая крупная $-2,85 \times 2,4$ см, две средние $-2,9 \times 2,15 \mathrm{~cm}$, одна поменьше $1,3 \times 1,5$ см (рис. 5,3,4,6). Все сердоликовые бусы (рис. 5,4-7) также однотипные - тип 36 [Алексеева, 1982, с. 16]. Но среди них (всего 57 экз.) выделяются бусы плавных биконических очертаний двух размерных вариантов (крупные - 45 экз., мелкие - 10 экз.) и два почти цилиндрические изделия с ровно срезанными заполированными торцами. Камень полупрозрачный, светлый, редко с темными коричневыми прожилками и пятнышками.

Разнообразными типами представлены бусы из стекла с внутренней позолотой [Алексеева, 1978, с. 29-32]. В состав ожерелья входила только одна биконическая поперечно сжатая бусина типа 8 (рис. 5,5). Остальные бусы (рис. $5,1,2$ ) были найдены в области запястий, щиколоток, а также справа от скелета, в отдельной кучке предметов: округлые пропорциональные типа 1а (2 экз.); бочковидная пропорциональная типа 2a; удлиненные цилиндрические типа 4 (4 экз.); короткоцилиндрические типа 5 (2 экз.); округло-ребристые типа 9 (4 экз.); короткоцилиндрические с поперечным поясом бугорков типов 15 и 16 (всего 16 экз.).

Бус из одноцветного стекла - всего два типа. Одни из них - уплощенная пронизь из полупрозрачного темно-синего стекла типа 167 (рис. 5,2), характерного для II-I вв. до н.э. [Алексеева, 1978, с. 73]. На ногах был най- ден многочисленный рубленый бисер (34 экз.) из прозрачного темно-синего стекла типа 166 [Алексеева, 1978, с. 72].

Перечисленные типы бус, в целом характерные для эпохи эллинизма, в сарматских и меотских погребениях Прикубанья были особенно распространены во II-I вв. до н.э.

В группе предметов (реальгар, «оселок», нуклеус), которые могут быть связаны с культовыми действиями, под венчиком мисочки были найдены три глиняных пряслица (рис. 2, 1-3). Как отмечает М.Г. Мошкова, посвятившая специальную работу роли пряслиц в мужских сарматских погребениях, они могли играть роль «амулетов или амулетов-оберегов». В богатых погребениях с золотыми вещами их нередко находят по несколько штук [Мошкова, 2012, с. 193, 194].

Маленькая сероглиняная мисочка (рис. 2,12) с отогнутым краем относится к типу сосудов местного производства, особенно широко использовавшихся в погребальном обряде меотов во второй половине II в. до н.э. [Лимберис, Марченко, 2005, с. 239, хронол. табл.]. В сарматских погребениях Прикубанья такие мисочки / чашечки также встречаются, по крайней мере, до середины I в. до н.э. [Марченко, 1996, рис. 29,54; Marčenko, Limberis, 2008, s. 381, 382, Taf. 37,2, Taf. 41,5, Kat.-Nr. 20, 23].

В погребение был положен полный колчан стрел (более 80 экз.). Типы железных втульчатых трехлопастных наконечников обычные для II-I вв. до н.э. (рис. 2,6,7). Такое большое количество наконечников стрел крайне редко встречается в сарматских комплексах Прикубанья. Два наконечника лежали отдельно от колчана, справа от скелета, у голеностопного сустава. С этой же стороны был прослежен тлен от узкого деревянного предмета слегка изогнутой формы и длиной 55 см. Хотелось бы предположить, что это отпечаток лука, а не плашки перекрытия, которое располагалось поперек могильной ямы.

Таким образом, вещевой комплекс погребения в целом характерен для II-I вв. до н.э. Самая поздняя вещь - бронзовый перстень, хронология которого уходит в первые века н.э. и для Прикубанских материалов пока детально не разработана. Несмотря на то что узко да- 
Н.Ю. Лимберис, И.И. Марченко. Сарматское погребение из кургана «Кирпичный» в Прикубанье

тирующихся предметов в погребении нет, наиболее реальным представляется ограничить его датировку I в. до н.э. Наличие дорогих и сакральных предметов и, что немаловажно, полного колчана стрел позволяет отнести погребение из кургана «Кирпичный» к разряду элитных захоронений сиракской знати (типа «Овального» и Новокорсунской).

\section{ПРИМЕЧАНИЕ}

${ }^{1}$ Исследование выполнено при финансовой поддержке РФФИ, проект № 18-09-00619 «Военное дело меотов правобережья Кубани (VI в. до н.э. III в. Н.э.».

The work was supported by RFBR, project no. 18-09-00619 "Military Art of Meots of the Right Bank of Kuban $\left(6^{\text {th }}\right.$ Century BC $-3^{\text {rd }}$ Century AD)". 


\section{ИЛЛЮСТРАЦИИ}

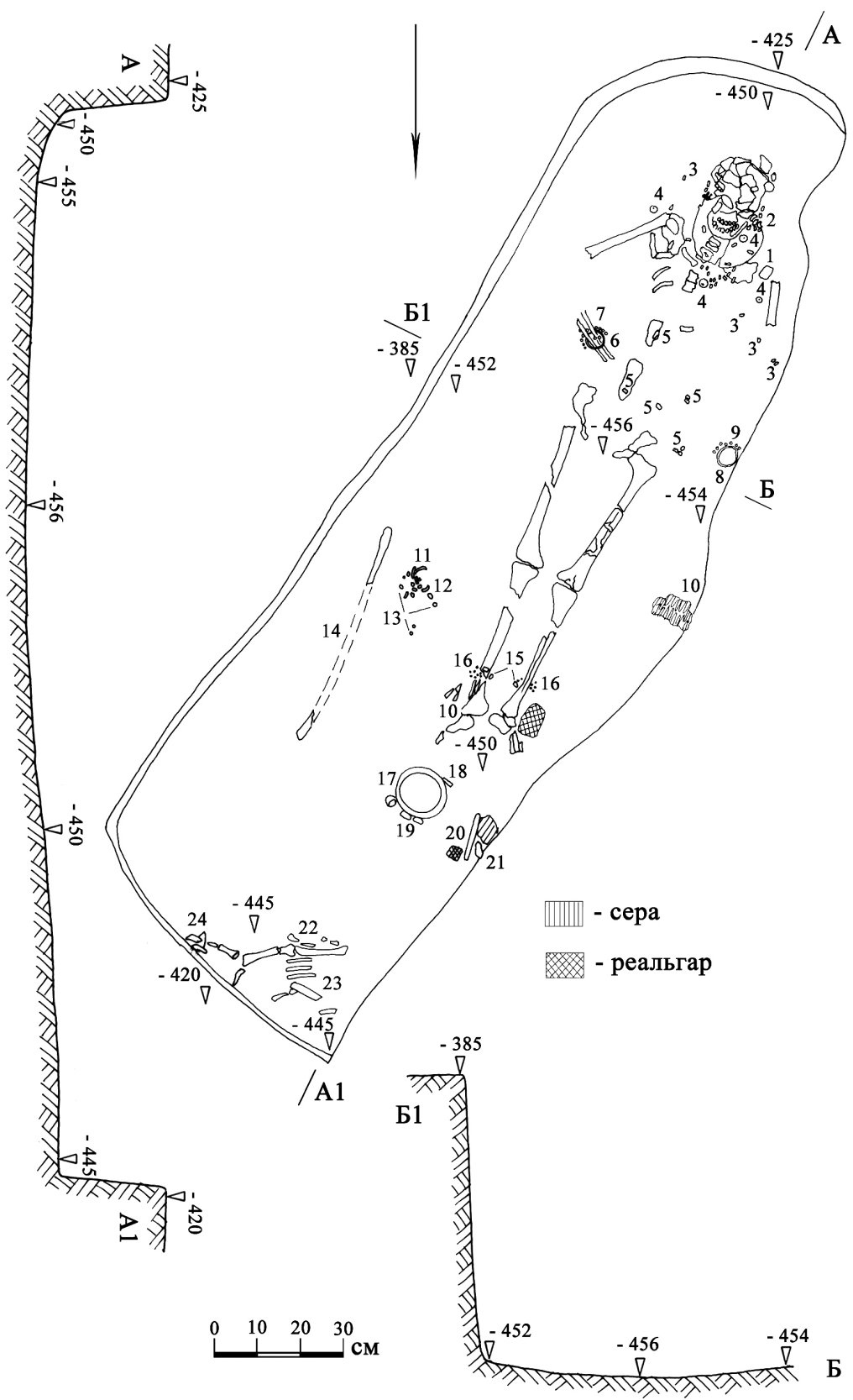

Рис. 1. План и разрезы могильной ямы:

1 - бронзовое зеркало; 2 - золотая серьга; 3 - сердоликовые бусы; 4 - халцедоновые бусы; 5 - серебряные бляшки: 6 - золотой браслет; 7 - стеклянные бусы; 8 - золотой браслет; 9 - стеклянные бусы;

10 - железные наконечники стрел; 11 - железный браслет; 12 - бронзовый перстень; 13 - стеклянные бусы; 14 - отпечаток деревянного предмета; 15 - стеклянные бусы; 16 - стеклянный бисер; 17 - сероглиняная чашечка; 18 - железный нож; 19 - глиняные пряслица; 20 - «оселок»; 21 - кремневый нуклеус; 22 - кости барана; 23 - железный нож; 24 - железное шило

Fig. 1. Plan and cross-section views of the grave pit:

1 - bronze mirror; 2 - gold earring; 3 - cornelian beads; 4 - chalcedony beads; 5 - silver plaques; 6 - gold bracelet; 7 - glass beads; 8 - gold bracelet; 9 - glass beads;

10 - iron arrowheads; 11 - iron bracelet; 12 - bronze fingering; 13 - glass beads;

14 - wooden item trail; 15 - glass beads; 16 - small glass beads; 17 - small grey clay bowl; 18 - iron knife; 19 - clay spindles; 20 - "whetstone"; 21 - flint nucleus; 22 - sheep bones; 23 - iron knife; 24 - iron awl 

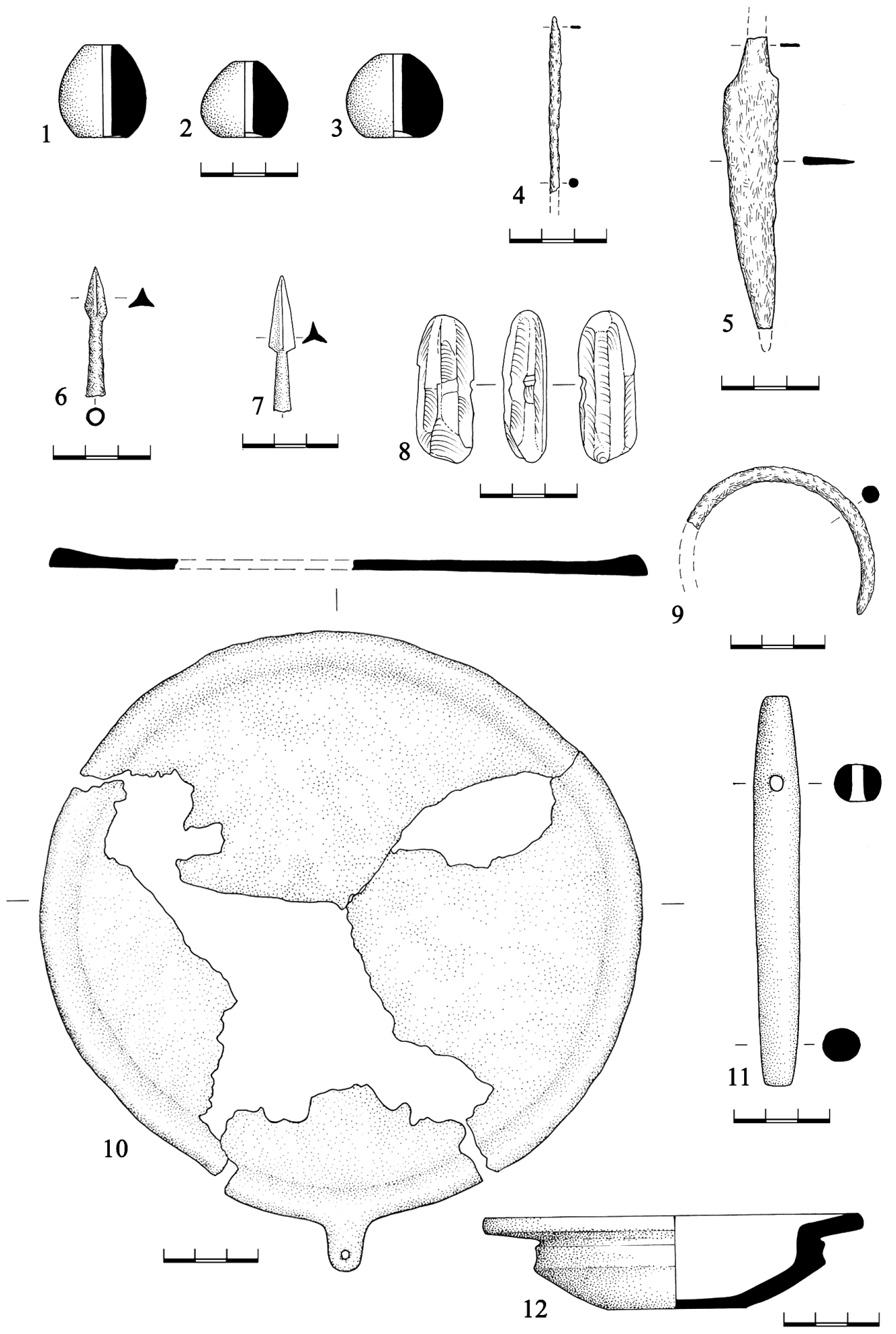

Рис. 2. Погребальный инвентарь:

1-3 - глиняные пряслица; 4 - железное шило; 5 - железный нож; 6, 7 - типы железных наконечников стрел; 8 - кремневый нуклеус; 9 - железный браслет; 10 - бронзовое зеркало; 11 - «оселок» (пробирный камень); 12 - сероглиняная чашечка

Fig. 2. Grave goods:

1-3 - clay spindles; 4 - iron awl; 5 - iron knife; 6, 7 - types of iron arrowheads; 8 - flint nucleus; 9 - iron bracelet; 10 - bronze mirror; 11 - "whetstone" (assay stone); 12 - small grey clay bowl 
N.Yu. Limberis, I.I. Marchenko. The Sarmatian Burial from “Kirpichnyy” Barrow in Kuban Region
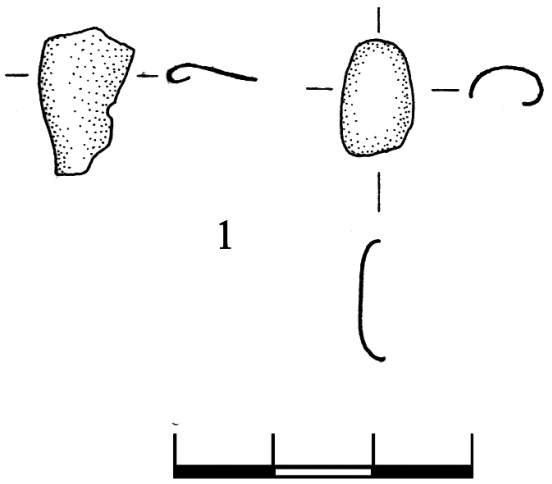

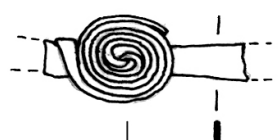

2
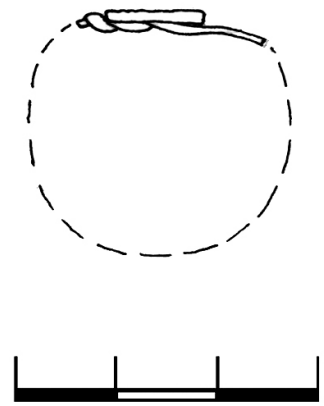
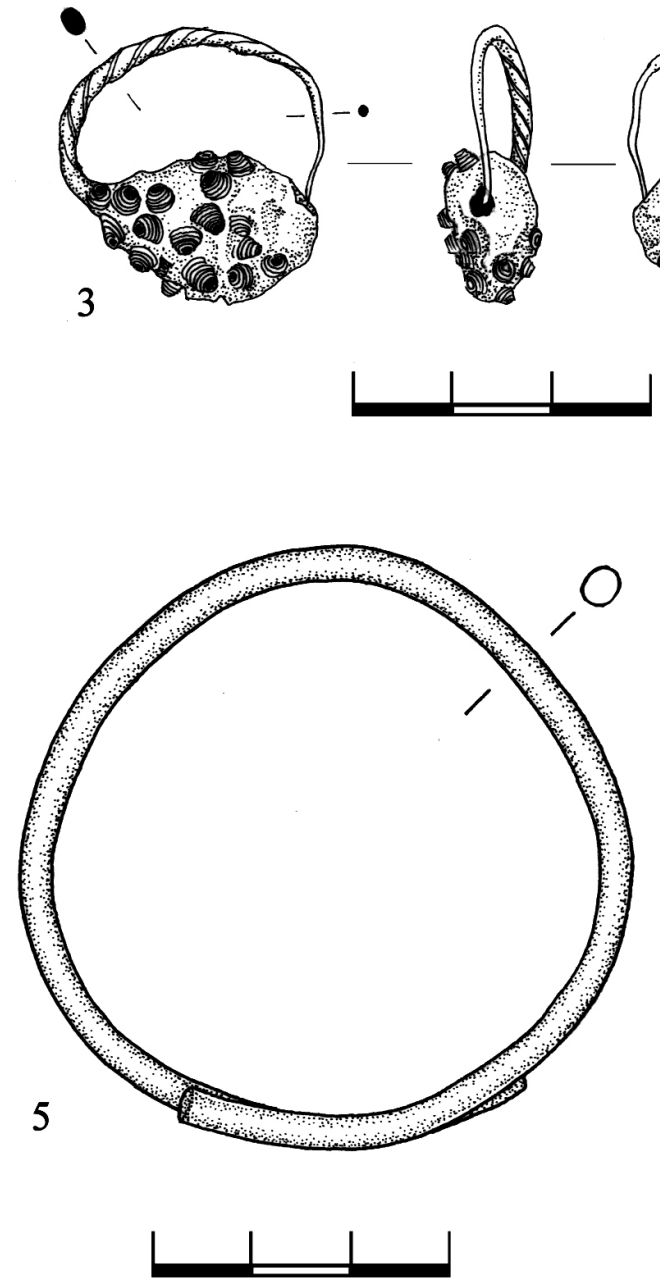

Рис. 3. Погребальный инвентарь:

1 - серебряные бляшки; 2 - бронзовый перстень; 3, 4- золотые серьги; 5, 6- золотые браслеты

Fig. 3. Grave goods:

1 - silver plaques; 2 - bronze fingering; 3, 4- gold earrings; 5, 6 - gold bracelets 
Н.Ю. Лимберис, И.И. Марченко. Сарматское погребение из кургана «Кирпичный» в Прикубанье

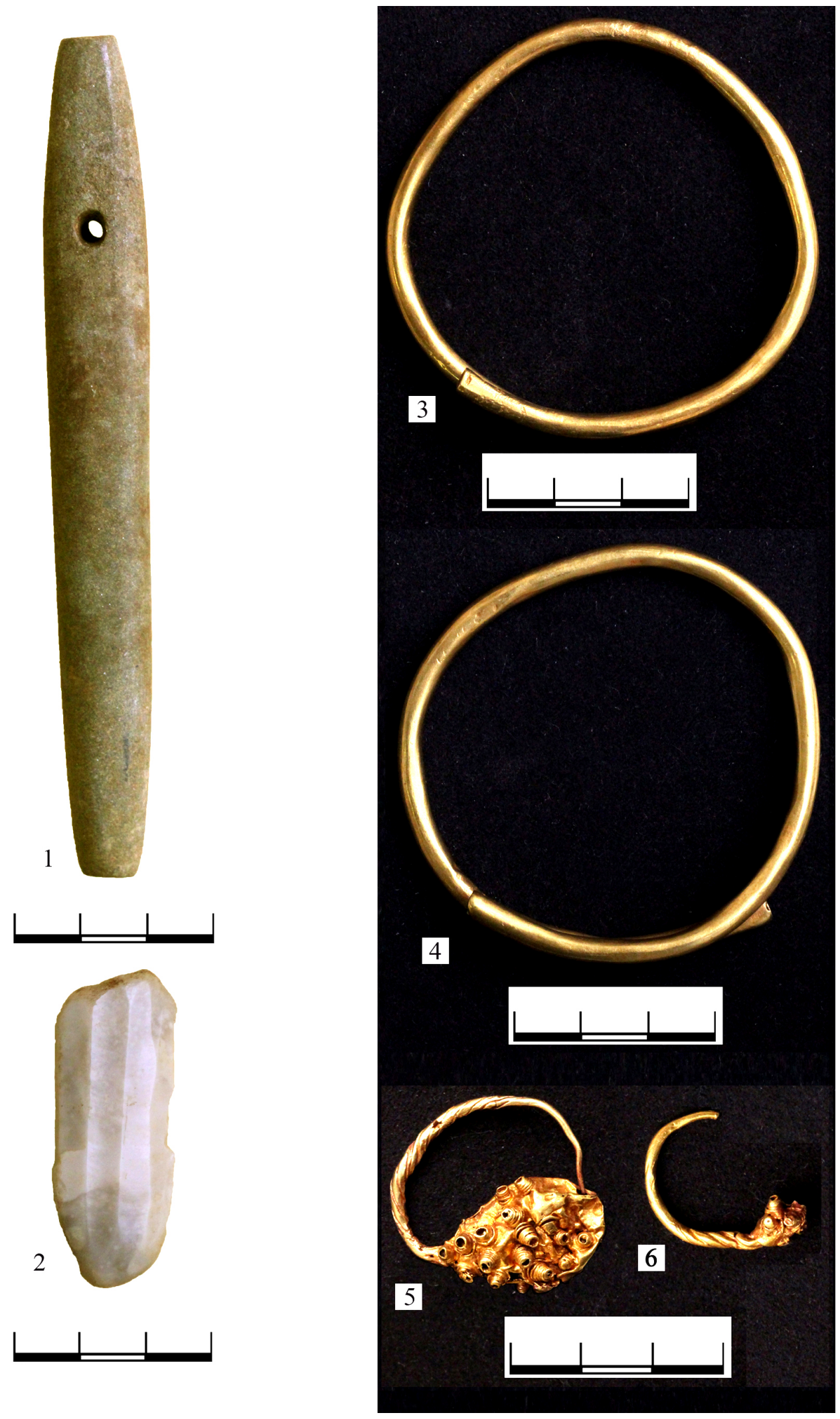

Рис. 4. Инвентарь погребения (фото):

1 - «оселок» (пробирный камень); 2 - кремневый нуклеус; 3, 4 - золотые браслеты; 5, 6 - золотые серьги

Fig. 4. Grave goods (photo):

1 - "whetstone" (assay stone); 2 - flint nucleus; 3, 4- gold bracelets; 5, 6- gold earrings 

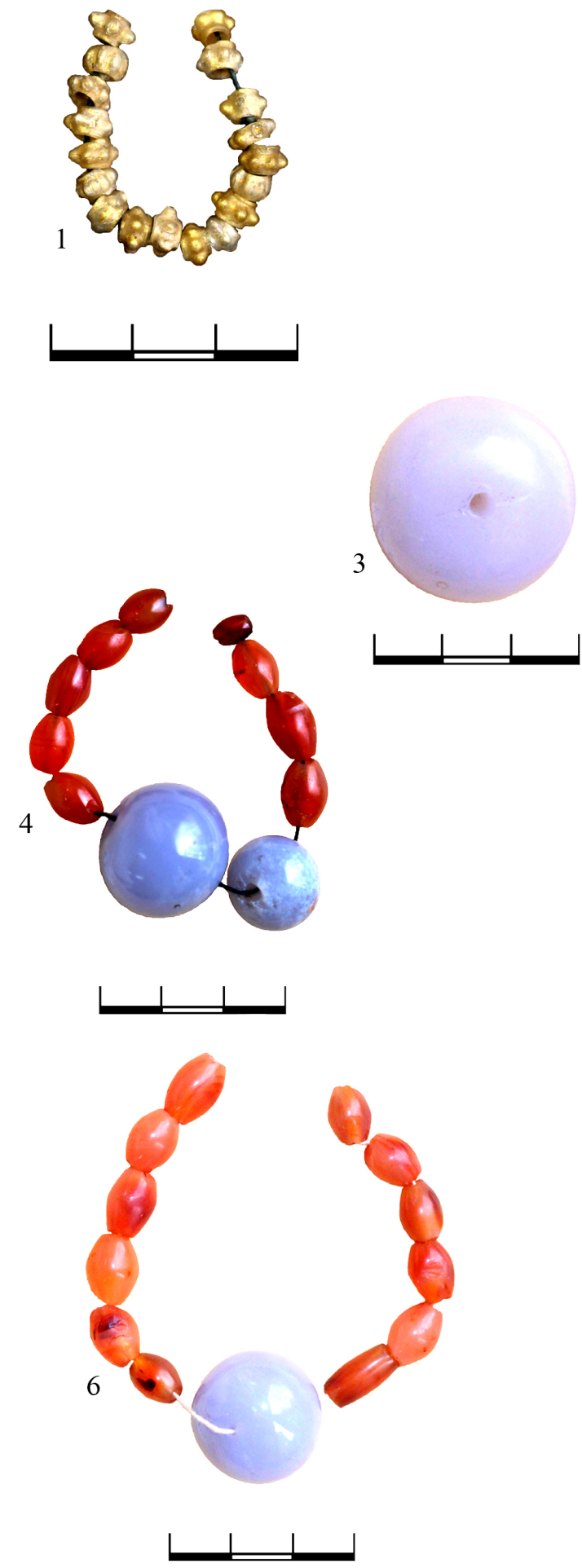

Рис. 5. Бусы из погребения (фото):

1 - стекло с внутренней позолотой (типы $9,15,16$ );

2 - стекло одноцветное (тип 167), стекло с внутренней позолотой (типы 1a, 2a, 4, 5, 9);

3 - халцедон (тип 4a); 4, 6- сердолик (тип 3б), халцедон (тип 4a);

5 - сердолик (тип 3б) и одна стеклянная с внутренней позолотой (тип 8); 7 - сердолик (тип 3б)

Fig. 5. Beads from the burial (photo):

1 - glass with internal gilding (types $9,15,16$ );

2 - monochrome glass (type 167), glass with internal gilding (types 1a, 2a, 4, 5, 9); 3 - chalcedony (type 4a); 4, 6 - cornelian (type 36), chalcedony (type 4a);

5 - cornelian (type 36) and one glass bead with internal gilding (type 8); 7 - cornelian (type 36) 


\section{СПИСОК ЛИТЕРАТУРЫ}

Алексеева Е. М., 1978. Античные бусы Северного Причерноморья. САИ. Г1-12. М. : Наука. $120 \mathrm{c}$.

Алексеева Е. М., 1982. Античные бусы Северного Причерноморья. САИ. Г1-12. М. : Наука. $104 \mathrm{c}$.

Аникеева О. В., 2010. «Оселки» - пробирные камни из Филипповки // Археология и палеоантропология Евразийских степей и сопредельных территорий. М. : Таус. С. 192-206.

Аникеева О. В., Яблонский Л. Т., 2012. Так называемые оселки сарматского времени из могильника Филипповка 1: естественнонаучные исследования // Культуры степной Евразии и их взаимодействие с древними цивилизациями : материалы междунар. науч. конф., посвященной 110-летию со дня рождения выдающегося российского археолога Михаила Петровича Грязнова. Кн. 1. СПб. : Периферия. С. 47-53.

Анфимов И. Н., Анфимов Н. В., 1992. Археологические памятники города Краснодара // Кубанский краевед. Вып. 5. С. 19-60.

Анфимов Н. В., 1961. Тахтамукаевский могильник (аул Октябрьский) // Сборник материалов по археологии Адыгеи. T. II. (Серия археологическая). Майкоп : Адыгейское книжное издво. С. 188-207.

Богданова Н. А., 1989. Могильник первых веков нашей эры у с. Заветное // Археологические исследования на юге Восточной Европы. Труды ГИМ. Вып. 70. М. : ГИМ. С. 17-70.

Глебов В. П., Толочко И. В., 2016. Женские погребения с оружием на Нижнем Дону в эпоху позднего эллинизма: Танаис и сарматы // Античная цивилизация и варварский мир Понто-Каспийского региона. Материалы Всероссийской научной конференции с международным участием, посвященной 70-летнему юбилею Б.А. Раева (Кагальник, 20-21 окт. 2016 г.). Ростов н/Д: ЮНЦ РАН. С. 44-84.

Гущина И. И., Журавлев Д. В., 2016. Некрополь римского времени Бельбек IV в юго-западном Крыму. Ч. 1. Труды ГИМ. Вып. 205. М. : ГИМ. $272 \mathrm{c}$.

Гущина И. И., Засецкая И. П., 1989. Погребения зубовско-воздвиженского типа из раскопок Н.И. Веселовского в Прикубанье (І в. до н.э. начало II в. н.э.) // Археологические исследования на юге Восточной Европы. Труды ГИМ. Вып. 70. М. : ГИМ. С. 71-141.

Кононов В. Ю., 2006. Типология и хронология перстней и колец из меотских и сарматских памятников Кубани // Материалы и исследования по археологии Кубани. Вып. 6. С. 124-133.
Корпусова В. Н., 1983. Некрополь Золотое (К этнокультурной истории европейского Боспора). Киев : Наукова думка. 182 с.

Кухаренко Ю. В., 1959. Распространение латенских вещей на территории Восточной Европы // Советская археология. № 1. С. 31-51.

Лимберис Н. Ю., Марченко И. И., 2003. Стеклянные сосуды эллинистического и римского времени из Прикубанья // МИАК. Вып. 3. Краснодар : Изд-во КубГУ. С. 106-183.

Лимберис Н. Ю., Марченко И. И., 2005. Хронология керамических комплексов с античными импортами из раскопок меотских могильников правобережья Кубани // Материалы и исследования по археологии Кубани. Вып. 5. Краснодар : Изд-во КубГУ. С. 219-324.

Малышев А. А., Трейстер М. Ю., 1994. Погребение Зубовского-Воздвиженского типа в окрестностях Новороссийска // Боспорский сборник. Вып. 5. М. : [б. и.]. С. 59-86.

Максименко В. Е., 1983. Савроматы и Сарматы на Нижнем Дону. Ростов н/Д : Изд-во Ростовского государственного университета. 224 с.

Марченко И. И., 1996. Сираки Кубани (По материалам курганных погребений Нижней Кубани). Краснодар : Изд-во КубГУ. 338 с.

Мордвинцева В. И., Трейстер М. Ю., 2007. Произведения торевтики и ювелирного искусства в Северном Причерноморье II в. до н.э. - II в. н.э. T. 1. Симферополь ; Бонн : Тарпан. 308 с.

Мордвинцева В. И., Хачатурова Е. А., Юрченко Т. В., 2010. Сокровища Древней Кубани. Симферополь; Краснодар : Универсум. 448 с.

Мошкова М. Г., 1963. Памятники прохоровской культуры. САИ. Вып. Д1-10. М. : Изд-во АН СССР. 56 с. + табл.

Мошкова М. Г., 2012. О назначении пряслиц в погребениях мужчин // Евразия в скифо-сарматское время. Памяти Ирины Ивановны Гущиной. Труды ГИМ. Вып. 191. М. : ГИМ, c. $189-194$.

Пуздровский А. Е., 2007. Крымская Скифия II в. до н.э. - III в. н.э. Погребальные памятнки. Симферополь : Бизнес-Информ. 480 с.

Раев Б. А., 1993. Бронзовая посуда позднего латена в Сарматии // Античный мир и археология. Проблемы истории и археологии древней ойкумены. Вып. 9. Саратов : Изд-во СГУ. С. 160-175.

Скрипкин А. С., 1984. Два погребения раннего железного века из Прикубанья // Древности Евразии в скифо-сарматское время. М. : Наука. С. 218-224.

Трейстер М. Ю., 1992а. Бронзолитейное ремесло Боспора // Археология и искусство Боспора. Сообщения ГМИИ им. А.С. Пушкина. Вып. 10. C. 66-110. 
Трейстер М. Ю., 1992б. Кельти у Північному Причорномор'ї // Археологія. № 2. С. 37-50.

Храпунов И. Н., 2006. Погребения детей в могильнике Нейзац // Материалы по археологии, истории и этнографии Таврии. Вып. XII. Ч. 1. Симферополь : [б. и.]. С. 161-250.

Шилов В. П., 1975. Очерки по истории древних племен Нижнего Поволжья. Ленинград : Наука. $207 \mathrm{c}$.

Эрлих В. Р., Чандрасекаран С., 2013. Украшения эллинистического времени из могильника Псенафа (Адыгея) // Боспорский феномен. Греки и варвары на евразийском перекрестке. СПб. : Нестор-История. С. 667-675.

Эрлих В. Р., 2014. Древности «Долины яблонь». Каталог выставки. М. : Государственный музей Востока. $144 \mathrm{c}$.

Marčenko I. I., Limberis N. Ju., 2008. Römische importe in sarmatischen und maiotischen Denkmälern des Kubangebietes. Archäologie in Eurasien (25). Mainz : [s. n.]. S. 265-400, 222 taf.

\section{REFERENCES}

Alekseeva E.M., 1978. Antique Beads of the Northern Pontic Region. Svod arkheologicheskih istochnikov, iss. G1-12. Moscow, Nauka Publ. 120 p. (in Russian).

Alekseeva E.M. 1982. Antique Beads of the Northern Pontic Region. Svod arkheologicheskih istochnikov, iss. G1-12. Moscow, Nauka Publ. 104 p. (in Russian).

Anikeeva O.V., 2010. The "Whetstones" - Assay Stones from Filippovka. Arkheologiya $i$ paleoantropologiya Evraziyskikh stepey $i$ sopredel'nykh territoriy. Moscow, Taus Publ., pp. 192-206. (in Russian).

Anikeeva O.V., Yablonsky L.T. So-called "Whetstones" of the Sarmatian Time from the Burial Ground Filippovka 1: Natural Science Research. Kul'tury stepnoy Evrazii i ikh vzaimodeystvie $s$ drevnimi tsivilizatsiyami : materialy mezhdunar. nauch. konf., posvyasch. 110-letiyu so dnya rozhdeniya vydayusch. ros. arkheologa Mikhaila Petrovicha Gryaznova, book 1. Sankt Peterburg, Periferiya Publ., pp. 4753. (in Russian).

Anfimov I.N., Anfimov N.V., 1992. Archaeological Monuments of the City of Krasnodar. Kubanskiy kraeved, iss. 5, pp. 19-60. (in Russian).

Anfimov N.V., 1961. Tahtamukayevsky Burial Ground. Sbornik materialov po arkheologii Adygei, vol. II (Seriya arkheologicheskaya). Maykop, Adygeyskoe knizhnoe izd-vo Publ., pp. 188-207. (in Russian).
Bogdanova N.A., 1989. The Burial Ground of the First Centuries BC Near the Village Zavetnoye. Arkheologicheskie issledovaniya na yuge Vostochnoy Evropy. Trudy GIM, iss. 70. Moscow, SHM, pp. 17-70. (in Russian).

Glebov V.P., Tolochko I.V., 2016. Female Burials with Weapons on the Lower Don in the Late Hellenistic Time: Tanais and Sarmatians. Antichnaya civilizaciya $i$ varvarskiy mir PontoKaspiyskogo regiona : materialy Vseros. nauch. konf. s mezhdunar. uchastiem, posvyashch. 70-letnemu yubileyu B.A. Raeva. Kagal 'nik, 20-21 oktyabrya 2016 g. Rostovna-Donu: SSC RAS, pp. 44-84. (in Russian).

Guschina I.I., Zhuravlev D.V., 2016. Roman Necropolis Belbek IV in the South-Western Crimea, part 1. Trudy GIM, vol. 205. Moscow, SHM, 272 p. (in Russian).

Guschina I.I., Zasetskaya I.P., 1989. ZubovskyVozdvizhensy Type Burials from Excavations of N.I. Veselovsky in the Kuban Region. Arkheologicheskie issledovaniya na yuge Vostochnoy Evropy. Trudy GIM, iss. 70. Moscow, SHM, pp. 71-141. (in Russian).

Kononov V.Yu., 2006. Typology and Chronology of the Fingerings from the Maeotian and Sarmatian Monuments of the Kuban. Materialy $i$ issledovaniya po arkheologii Kubani, iss. 6. Krasnodar, pp. 124-133. (in Russian).

Korpusova V.N., 1983. Necropolis Zolotoye (Towards the Ethnocultural History of European Bosporus). Kiev, Naukova dumka Publ., 182 p. (in Russian).

Kukharenko Yu.V., 1959. Distribution of Latin Objects in Eastern Europe. Sovetskaya Arkheologiya, no. 1, pp. 31-51. (in Russian).

Limberis N.Yu., Marchenko I.I., 2003. Hellenistic and Roman Glass Vessels from Kuban Region. Materialy $i$ issledovaniya po arkheologii Kubani, iss. 3. Krasnodar, KubSU, pp. 106-183. (in Russian).

Limberis N.Yu., Marchenko I.I., 2005. Chronology of the Ceramics Complexes with Antique Imports from the Excavations of the Maeotian Burial Grounds on the Right Bank of the Kuban River. Materialy $i$ issledovaniya po arkheologii Kubani, iss. 5. Krasnodar, KubSU, pp. 219-324. (in Russian).

Malishev A.A., Treister M.Yu., 1994. The Burial of the Zubovsky-Vozdvizhensy Type in the Vicinity of Novorossiysk. Bosporskiy sbornik, iss. 5. Moscow, [s. n.], pp. 59-86. (in Russian).

Maximenko V.Ye., 1983. Sauromats and Sarmatians on the Lower Don. Rostov-na-Donu: Rostov state University, 224 p. (in Russian).

Marchenko I.I., 1996. The Siraci of the Kuban River basin (According to the materials of the burial 
mounds of the Lower Kuban). Krasnodar, KubSU, 337 p. (in Russian).

Mordvintceva V.I., Treister M.Yu., 2007. Works of Toreutics and Jewellery Art in the Northern Black Sea Region. $2^{\text {nd }}$ Century BC - $2^{\text {nd }}$ Century $A D$, vol. 1. Simferopol - Bonn, Tarpan, 308 p. (in Russian).

Mordvintceva V.I., Khachaturova E.A., Yurchenko T.V., 2010. Treasures of the Ancient Kuban. Simferopol - Krasnodar, Universum Publ., 448 p. (in Russian).

Moshkova M.G., 1963. Monuments of the Prokhorov culture. Svod arkheologicheskih istochnikov, iss. D1-10. Moscow, AS USSR, 56 p., tabl. (in Russian).

Moshkova M.G., 2012. On the Appointed the Spindles in the Burials of Men. Evraziya v skifosarmatskoe vremya. Pamyati Iriny Ivanovny Gushhinoy. Trudy GIM, vol. 191, Moscow, SHM, pp. 189-194. (in Russian).

Puzdrovsky A.Ye., 2007. Crimean Scythia $2^{\text {nd }}$ Century $B C-3^{\text {rd }}$ Century AD. Burial Monuments. Simferopol, Bisines-Inform Publ., 480 p. (in Russian).

Raev B.A., 1993. Late Latin Bronze Tableware in Sarmatia. Antichnyy mir i arheologiya. Problemy istorii $i$ arheologii drevney oykumeny, vol. 9. Saratov, SGU, pp. 160-175. (in Russian).

Skripkin A.S., 1984. Two Burials of the Early Iron Age from Kuban. Drevnosti Evrazii v skifo- sarmatskoe vremya. Moscow, Nauka Publ., pp. 218-224. (in Russian).

Treister M.Yu., 1992a. Bronze Castings of the Bosporus. Arkheologiya i iskusstvo Bospora. Soobshheniya Gosudarstvennogo Muzeya Izobrazitel 'nykh Iskusstv im. A.S. Pushkina, vol. 10. Moscow, The Pushkin State Museum of Fine Arts, pp. 66-110. (in Russian).

Treister M.Yu., 1992b. Celts in the Northern Pontic Region. Archaeology, no. 2, pp. 37-50. (in Ukrainian).

Khrapunov I.N., 2006. Children's Burials in the Cemetery of Neizats. Materialy po Arkheologii, Istorii $i$ Etnografii Tavrii, iss. XII, part 1. Simferopol, [s. n.], pp. 161-250. (in Russian).

Shilov V.P., 1975. Essays on the History of the Ancient Tribes of the Lower Volga. Leningrad, Nauka Publ., 207 p. (in Russian).

Erlich V.R., Chandrasekaran S., 2013. Jewellery of the Hellenistic Time from the Cemetery of Psenath (Adygea). Bosporskiy fenomen. Greki i varvary “ na evraziyskom perekrestke, Saint Petersburg, Nestor-Istoriya Publ., pp. 667-675. (in Russian).

Erlich V.R., 2014. The Antiquities of "The Valley of the Apple Trees". The Exhibition Catalogue. Moscow, The State Museum of Oriental Art, 144 p. (in Russian).

Marčenko I.I., Limberis N.Ju., 2008. Römische importe in sarmatischen und maiotischen Denkmälern des Kubangebietes. Archäologie in Eurasien (25), Mainz, [s. n.], s. 265-400, 222 taf. (in German).

\section{Information about the Authors}

Natalya Yu. Limberis, Senior Researcher, Scientific Research Institute of Archaeology, Kuban State University, Stavropolskaya St., 149, 350040 Krasnodar, Russian Federation, meot@mail.ru, https://orcid.org/ 0000-0003-0395-315X

Ivan I. Marchenko, Candidate of Sciences (History), Professor, Department of World History and International Relations, Kuban State University, Stavropolskaya St., 149, 350040 Krasnodar, Russian Federation, meot@mail.ru, https://orcid.org/0000-0001-7319-5214

\section{Информация об авторах}

Наталья Юрьевна Лимберис, старший научный сотрудник НИИ археологии, Кубанский государственный университет, ул. Ставропольская, 149, 350040 г. Краснодар, Российская Федерация, meot@mail.ru, https://orcid.org/0000-0003-0395-315X

Иван Иванович Марченко, кандидат исторических наук, профессор кафедры всеобщей истории и международных отношений, Кубанский государственный университет, ул. Ставропольская, 149, 350040 г. Краснодар, Российская Федерация, meot@mail.ru, https://orcid.org/0000-0001$7319-5214$ 